\title{
Influence of mouthwashes on the physical properties of orthodontic acrylic resin
}

\author{
Fabrício Mezzomo Collares, Flavia Veronezi Rostirolla, Érika de Oliveira Dias de Macêdo, \\ Vicente Castelo Branco Leitune, Susana Maria Werner Samuel
}

Universidade Federal do Rio Grande do Sul - UFRS, School of Dentistry, Area of Dental Materials, Porto Alegre, RS, Brazil

\begin{abstract}
Aim: The aim of this study was to evaluate the influence of acrylic resin immersion in different mouthwashes on hardness, roughness and color. Methods: Specimens of an orthodontic selfcured acrylic resin (Orto Clas ${ }^{\circledR}$ ) were produced and immersed in five mouthwashes: Plax Classic (Colgate $\left.{ }^{\circledR}\right)$; Plax ${ }^{\circledR}$ alcohol-free $\left(\right.$ Colgate $\left.^{\circledR}\right)$; Listerine ${ }^{\circledR}$ (Johnson \& Johnson $\left.{ }^{\circledR}\right)$; Periogard (Colgate $^{\circledast}$ ) and Periogard ${ }^{\circledR}$ alcohol-free (Colgate ${ }^{\circledast}$ ). Nine different immersion times were studied: $1,2,4,6,8,10,12,24 \mathrm{~h}$ and 7 days, totalizing 45 groups. The specimens were evaluated before and after immersion by Knoop microhardness $(n=5)$, roughness in Ra parameter $(n=5)$, and colorimetric analysis, CIElab ( $n=3)$. Results: All mouthwashes softened the acrylic resins after 7 days of immersion. Plax ${ }^{\dot{O}}$ alcohol-free showed no statistically significant difference of softening between the immersion times. Listerine ${ }^{\circledR}$ showed softening after immersion at all times. Plax ${ }^{\circledR}$ alcohol-free and Listerine ${ }^{\circledR}$ showed significantly increased values of roughness after $12 \mathrm{~h}$ of immersion $(\mathrm{p}<0.05)$. Listerine ${ }^{\circledast}$ presented a significant increase in color variation after $12 \mathrm{~h}$ of immersion. Conclusions: Immersion in mouthwashes could influence acrylic resin hardness, roughness and color.
\end{abstract}

Keywords: acrylic resins; mouthwashes; hardness.

\section{Introduction}

Orthodontic treatment for myofunctional therapies and small movements increase the surface microbial contamination of orthodontic appliances in the oral cavity ${ }^{1}$. Biofilm formation occurs on orthodontic wires ${ }^{2}$, clasps and springs ${ }^{3}$ and acrylic baseplates ${ }^{4}$. Acrylic removable devices are more prone to colonization due to subsurface porosities ${ }^{5}$. To avoid the biological proliferation tooth brushing seems to be an adequate way to perform the removal of the biofilm attached on the acrylic surface . However, factors such as age and manual dexterity of patients may interfere in the quality of its results 6 .

The use of antimicrobial agents, such as mouthwashes, can help maintaining the oral health of removable orthodontic appliance users bycontrolling the growth of biofilm ${ }^{7}$. The most commonly used mouthwashes for biofilm control due to their efficiency, are chlorhexidine ${ }^{8}$, triclosan ${ }^{9}$, cetylpyridinium chloride ${ }^{10}$ and essential oil-based ${ }^{11}$ solutions. On the other hand, a disinfectant for removable acrylic appliances should have no negative influence on the materials' properties after immersion. Immersion in solutions may cause plasticization of polymer chains, leading to material degradation by increased water sorption and solubility ${ }^{12}$.

Acrylic resin used for removable orthodontic appliances is a material that Universidade Federal do Rio Grande do Su Rua Ramiro Barcelos, 2492 - Rio Branco CEP 90035-003 - Porto Alegre, RS, Brasil Phone: +55 5133085198 E-mail: fabricio.collares@ufrgs.br and ability to be polished and disinfected ${ }^{14}$. Chemical disinfectants such as 
chlorhexidine, peroxides, sodium perborate, sodium hypochlorite and glutaraldehyde have shown surface and property alterations, such as transverse strength ${ }^{6,15}$, color stability ${ }^{16}$, roughness ${ }^{16-17}$ and hardness ${ }^{17}$ of acrylic resins subjected to chemical disinfection. An alternative for disinfection of acrylic baseplates is the home-care chemical solutions ${ }^{4}$. However, to the best of our knowledge there is no study evaluating long-term immersion of orthodontic acrylic resin devices in mouthwashes.

Therefore, the aim of this study was to evaluate the influence of mouthwashes on the properties of orthodontic acrylic resin. The null hypothesis tested is that the different solutions and immersion times have no influence on the microhardness and roughness of acrylic resin.

\section{Material and methods}

\section{Test Specimen Production}

A self-cured acrylic resin (Orto Clas ${ }^{\circledR}$; São Paulo, SP, Brazil) was manipulated according to the manufacturer's instructions and 360 square-shaped specimens $(10 \times 10 \times 5 \mathrm{~mm})$ were obtained. The sample consisted of 225 specimens for the microhardness and roughness tests $(n=5)$ and 135 specimens for the color test $(n=3)$. After polymerization, all specimens were visually inspected, and checked for a smooth surface without voids or porosity. Samples with voids or porosity were discarded. The specimens for the microhardness and roughness tests were embedded in a self-cured acrylic resin (JET; Campo Limpo Paulista, SP, Brazil), in order to prevent any problems with the alignment that could interfere in the tests. The samples for Knoop hardness and roughness tests had the acrylic resin excess removed during polishing using progressively 600 - to 1200 -grit silicon carbide paper (3M do Brasil; São Paulo, SP, Brazil). To obtain a smooth and flat surface, the specimens were finished with 220,400 and 600-grit sandpaper (Norton Abrasives; Saint-Gobain, Vinhedo, SP, Brazil) impregnated with a diamond suspension in a polishing machine (Arotec; Cotia, SP, Brazil) under water cooling. The specimens for color analysis were not polished.

Five commercial mouthwashes, Plax ${ }^{\circledR}$ Classic $\left(\right.$ Colgate $\left.^{\circledR}\right)$,
Plax ${ }^{\circledR}$ alcohol-free $\left(\right.$ Colgate $\left.^{\circledR}\right)$, Listerine ${ }^{\circledR}$ Cool Mint (Johnson \& Johnson $\left.^{\circledR}\right)$, Periogard ${ }^{\circledR}\left(\right.$ Colgate $\left.^{\circledR}\right)$ and Periogard ${ }^{\circledR}$ alcoholfree $\left(\right.$ Colgate $\left.^{\circledR}\right)$ were used. The used mouthwashes, as well as their composition and batch numbers, are shown in Table 1.

\section{Softening after Immersion}

The initial and final surface Knoop microhardness of each acrylic resin specimen was determined by using a hardness tester (HMV-2, Shimadzu, Tokyo, Japan). The longest diagonal of the indentation was measured and its value was used in the following formula to calculate KHN:

$\mathrm{KHN}=\left[(14228 \mathrm{c}) /\left(\mathrm{d}^{2}\right)\right]$

Where:

$\mathrm{c}=$ applied load in $\mathrm{g}$

$\mathrm{d}=$ length of the longest indentation diagonal in $\mathrm{mm}$ $14228=$ constant number

At first, 3 indentations were made on the surface of each specimen using a $15 \mathrm{~g}$ load for $10 \mathrm{~s}$ and the mean value from the 3 indentations was considered the specimen's KHN value. After the first measurement, the specimens were randomly divided into 45 groups $(n=5)$ in accordance with the immersion time and the tested mouthwashes. The groups were immersed in $30 \mathrm{~mL}$ of $\mathrm{Plax}^{\circledR}$ Classic, Plax ${ }^{\circledR}$ alcoholfree, Listerine ${ }^{\circledR}$, Periogard ${ }^{\circledR}$ and Periogard ${ }^{\circledR}$ alcohol-free mouthwashes for $1,2,4,6,8,10,12,24 \mathrm{~h}$ and 7 days. After mouthwash immersion the specimens were washed with distilled water for $10 \mathrm{~s}$ and dried with compressed air for 1 minute. Then, the second microhardness measurements were made as described for the initial measurements. The softening of acrylic resin $(\triangle \mathrm{KHN})$ was recorded as the percent difference between final and initial Knoop microhardness $\left(\mathrm{KHN}_{\mathrm{F}}-\mathrm{KHN}_{\mathrm{I}}\right)$.

\section{Roughness}

Mean surface roughness from each specimen was obtained from 3 measurements in different areas using a roughness surface analyzer (SJ-201 Mitutoyo, Tokyo Japan). The surface roughness $\mathrm{Ra}$ is the value assigned to the area peaks and valleys divided by the distance traveled by the sensor in a straight line, providing roughness $\mathrm{Ra}$ in $\mu \mathrm{m}$. The roughness surface analyzer provides the average of three 0.25

Table 1. Mouthwashes, composition and batch numbers of used solutions.

\begin{tabular}{lll}
\hline Material & \multicolumn{1}{c}{ Composition } & Batch numbers \\
Plax ${ }^{\otimes}$ Classic & Aqua, sorbitol, alcohol, glycerin, sodium lauryl sulfate, sodium methyl cocoyl taurate, PVM/MA copolymer, \\
& aroma, dosodium phosphate, sodium hydroxide, triclosan, sodium saccharin, $\mathrm{Cl} 16035$ & BR122A
\end{tabular}

Plax $^{\circledast}$ alcohol-free $\quad$ Aqua, glycerin, propylene glycol, sorbitol, PEG-40 hydrogenated castor oil, aroma, phosphoric acid, sodium

BR123B benzoate, cetylpiridinium chloride, sodium fluoride $0.05 \%$, sodium saccharin sodium saccharin, sodium benzoate, $\mathrm{Cl} 42053$ 
$\mu \mathrm{m}$ lines. The specimens for the roughness test were the same as those used in the microhardness test (Figure 1). After the initial measurements were made, the specimens were randomly divided into 45 groups $(n=5)$ in accordance with the time of immersion and the tested chemical solutions. The specimens from each group were immersed in $30 \mathrm{~mL}$ of each mouthwash for $1,2,4,6,8,10,12,24 \mathrm{~h}$ and 7 days. After the mouthwash immersion each specimen was washed with distilled water for $10 \mathrm{~s}$ and dried with compressed air for $1 \mathrm{~min}$. Then, the second roughness measurements were made in the same way as described for the initial measurement. The difference was calculated.

\section{Colorimetric Analysis}

The 135 specimens were randomly divided in 5 groups $(n=45)$, each one subdivided into $9(n=3)$, as for the roughness and hardness evaluation. Color measurements (CM2600, Konica Minolta, Osaka, Japan) were made before and after the immersion times. Color was assessed by measurements of $\mathrm{L}^{*} \mathrm{a} * \mathrm{~b}^{*}$ coordinates with D65 CIE illuminant (average daylight) and a 10 degree viewing angle geometry. $L^{*}$ represents the lightness or darkness of the object. a* represents the red-green chromaticity of the object ( $+\mathrm{a}^{*}$ towards red and $-\mathrm{a}^{*}$ towards green). $\mathrm{b}^{*}$ represents the yellow-blue chromaticity of the object $\left(+b^{*}\right.$ towards region and $-b^{*}$ towards blue). Three measurements were made in each sample and the mean value was recorded. Color variation of specimens $(\Delta E)$ was calculated between the initial measurement and after each immersion interval using the following equation:

$\left.\Delta \mathrm{E}=\left(\left[\Delta \mathrm{L}^{*}\right]\right)^{2}+\left(\left[\Delta \mathrm{a}^{*}\right]\right)^{2}+\left(\left[\Delta \mathrm{b}^{*}\right]\right)^{2}\right)^{1 / 2}$

After three measurements for each group, the mean values of $\mathrm{L}^{*}, \mathrm{a}^{*}$ and $\mathrm{b}^{*}$ taken before and after immersion, the $\Delta \mathrm{E}$ value was calculated for each mouthwash and immersion time.

\section{Mouthwash pH}

The $\mathrm{pH}$ values from the chemical solutions were measured at room temperature $\left(20^{\circ} \mathrm{C}\right)$ using a digital $\mathrm{pH}$ meter $(\mathrm{pH} 21$, Hanna Instruments Inc., Woonsocket, RI, USA). The equipment was calibrated with deionized water before the samples were measured. Samples of $40 \mathrm{~mL}$ of each solution were analyzed before specimen immersion. After 5 measurements, the mean value for each mouthwash was recorded.

\section{Statistical Analysis}

The normality of data was evaluated using the Kolmogorof-Smirnov test. Statistical analysis was performed using two-way ANOVA (mouthwash and immersion time), one-way ANOVA $(\mathrm{pH})$ and Tukey's post-hoc test at a 0.05 level of significance.

\section{Results}

\section{Softening of Acrylic Resin by Microhardness}

All mouthwashes decreased the surface microhardness values after 7 days of immersion. Plax ${ }^{\circledR}$ alcohol-free showed no statistically significant differences among immersion times between $1 \mathrm{~h}$ to 7 days. At 7 days, Plax ${ }^{\circledR}$ alcohol-free showed lower value of softening than the other mouthwashes $(p<0.05)$. At 7 days, Periogard ${ }^{\circledR}$ showed its highest microhardness value over time $(p<0.05)$. Listerine ${ }^{\circledR}$ showed decrease in microhardness values in all tested times (Figure 2).

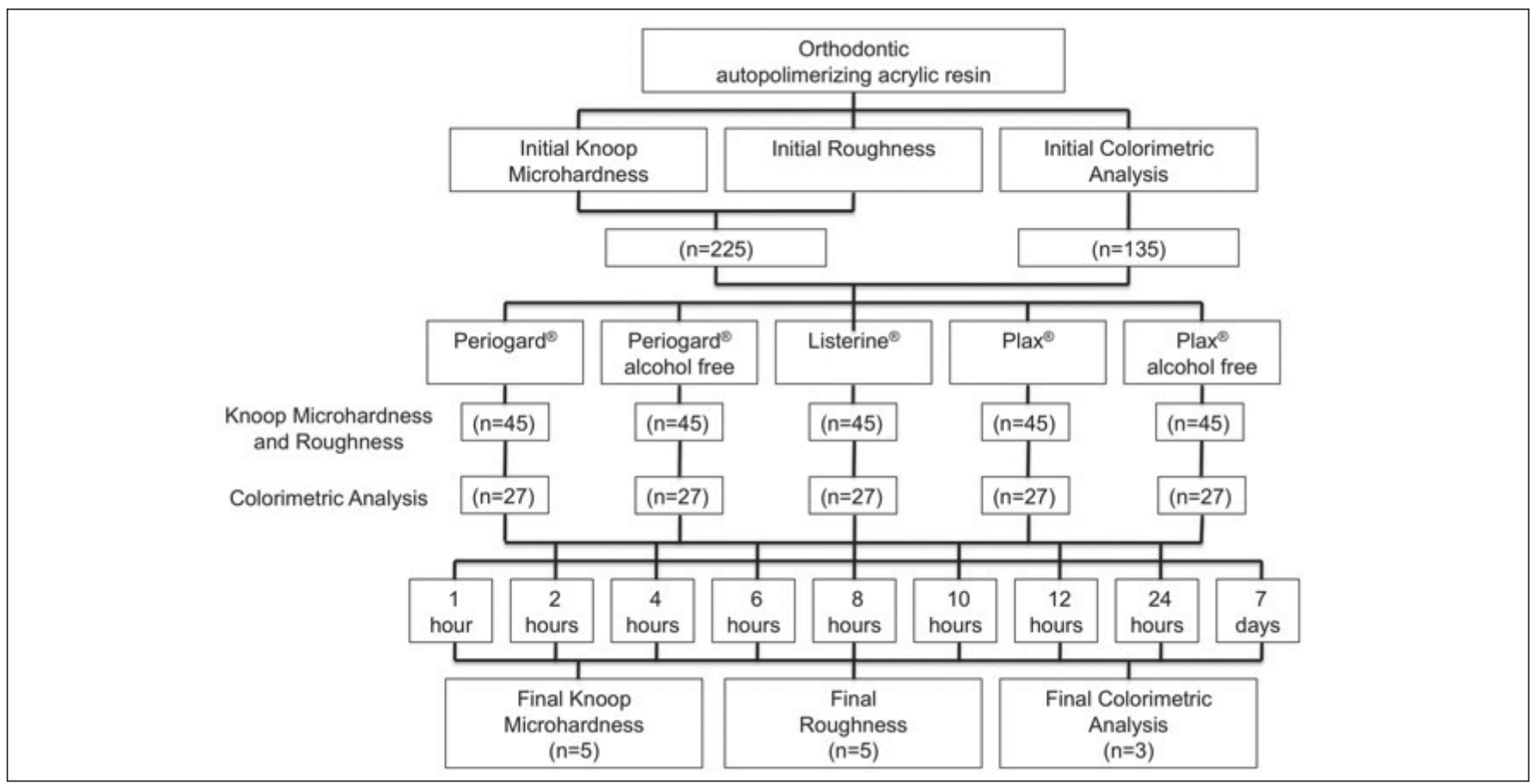

Fig. 1. Flowchart of the study methodology. 


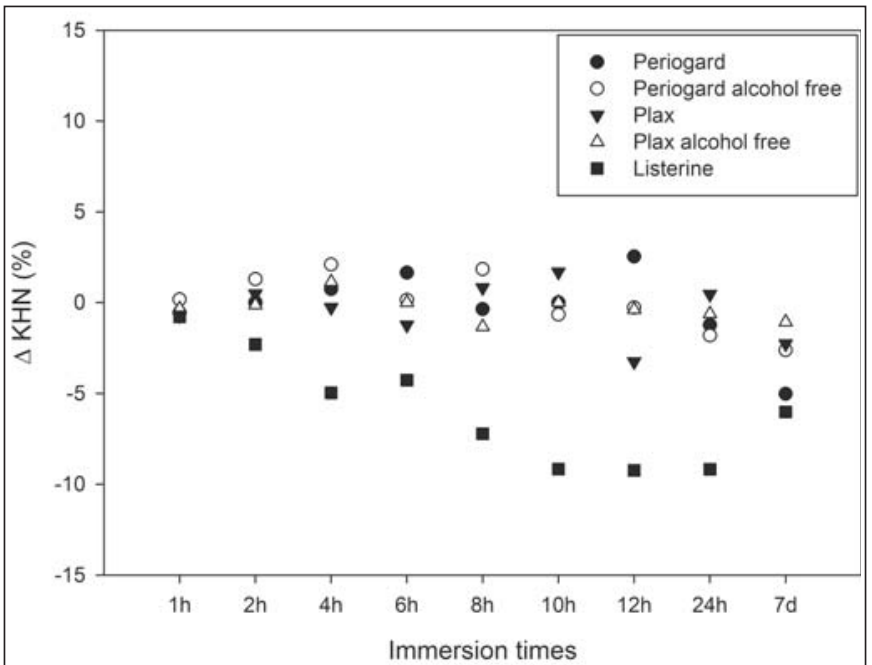

Fig. 2. Variation of Knoop hardness values after and before immersion in mouthwashes.

\section{Roughness}

The mouthwashes increased the surface roughness in all tested groups. However, only $\mathrm{Plax}^{\circledR}$ alcohol-free at $12 \mathrm{~h}$ and Listerine ${ }^{\circledR}$ at $12 \mathrm{~h}$ showed statistically significant increased values, within the same mouthwash and when compared with others $(p<0.05) . \Delta R a$ values are shown in Figure 3.

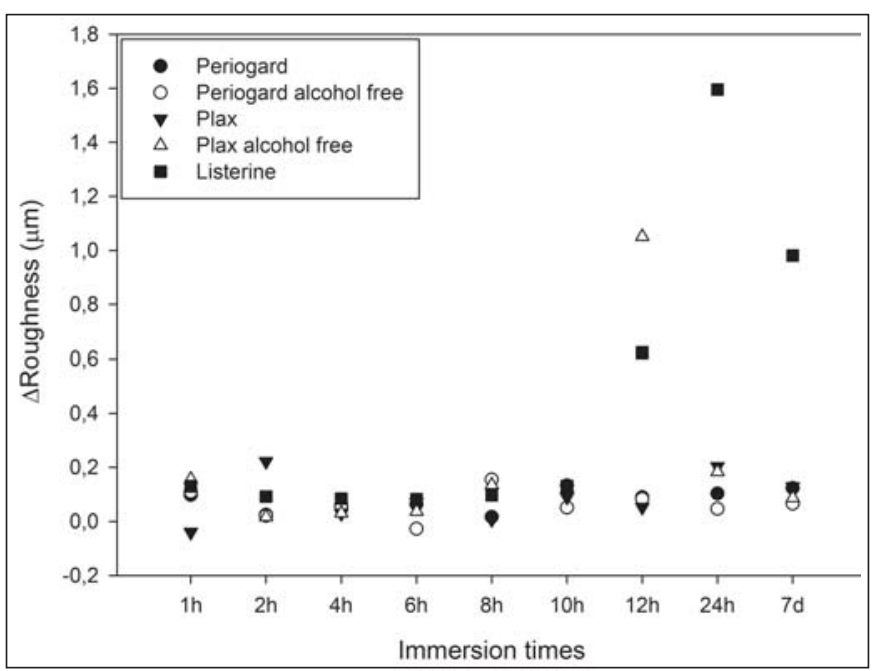

Fig. 3. Variation of roughness value, in $\mu \mathrm{m}$, after and before specimen immersion in mouthwashes.

\section{Colorimetric Analysis}

The colorimetric analysis using $\Delta \mathrm{E}$ revealed differences between times within each mouthwash (Figure 4). However, no significant difference was shown in $\mathrm{Plax}^{\circledR}$ alcohol-free, Plax $^{\circledR}$ Classic and Periogard ${ }^{\circledR}$ groups independent of time. When solutions were compared with each other, Listerine ${ }^{\circledR}$ was the only one presenting a significant increase in color variation after $12 \mathrm{~h}$ immersion.

\section{Mouthwash pH}

The $\mathrm{pH}$ solutions values ranged from $4.93( \pm 0.02)$ to

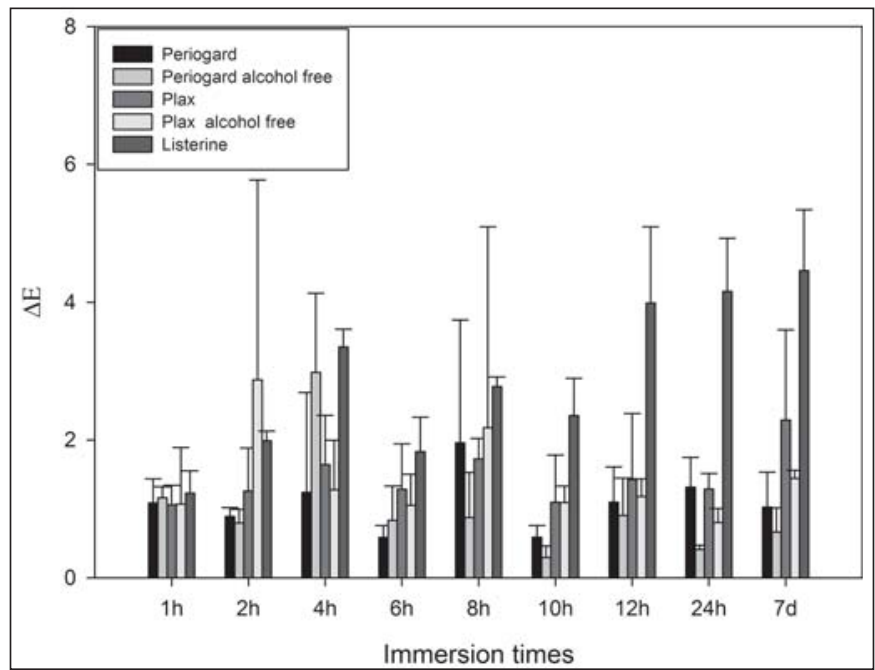

Fig. 4. Variation of $E$ value of colorimetric analyses for all immersion times in the mouthwashes.

$7.00( \pm 0.04)$, showing statistically significant difference among groups. Plax ${ }^{\circledR}$ Classic $\mathrm{pH}$ value was $7.00( \pm 0.04)$. Listerine $^{\circledR}$ showed the lowest $\mathrm{pH}$ (Table 2).

Table 2 - pH values of commercial mouthwashes before sample immersion.

\begin{tabular}{ll}
\hline Mouthwash & pH mean (SD) \\
Periogard ${ }^{\circledR}$ & $5.05( \pm 0.03)^{\mathrm{B}}$ \\
Periogard & $4.99( \pm 0.02)^{\mathrm{C}}$ \\
Listerine $^{\circledR}$ Cool Mint & $4.11( \pm 0.07)^{\mathrm{E}}$ \\
Plax $^{\circledast}$ Classic & $7.0( \pm 0.04)^{\mathrm{A}}$ \\
Plax $^{\circledast}$ alcohol-free & $4.93( \pm 0.02)^{\mathrm{D}}$ \\
\hline
\end{tabular}

${ }^{*}$ Different letters indicate statistically significant difference among the groups $(p<0.05)$.

\section{Discussion}

The use of removable orthodontic appliances (ROA) results in greater biofilm accumulation on dental surface and retentive sites of the appliance components ${ }^{1}$. Reducing the levels of microorganisms may prevent caries $^{18}$, halitosis ${ }^{19}$ and candidiasis $^{20}$. Therefore, antimicrobial agents, such as mouthwashes, have been advised for orthodontic patients to aid in the control of bacterial biofilm formation ${ }^{7}$. According to a systematic review, the mean wearing time of orthodontic removable appliances is $13.4( \pm 10.3)$ months $^{21}$. Based on this data, nine periods of immersion in mouthwashes were defined to simulate, and even extrapolate, situations at home disinfection practice by orthodontic patients, as a possible attempt to offer research-based data for a home disinfection protocol to be prescribed by orthodontists. Disinfection by immersion in chemical solutions, such as mouthwashes may predispose the acrylic resin to structural impairment due to sorption of water molecules and increase of solubility ${ }^{12}$. This study evaluated the effect of five of the most commonly used commercial mouthwashes, on the properties of an orthodontic self-cured acrylic resin. The results of this study showed that the acrylic resin properties were influenced by 
immersion in mouthwash solutions. Therefore, the null hypothesis was rejected.

Roughness of acrylic surface is of paramount importance to microorganism colonization on the acrylic surface. The five tested mouthwashes increased the acrylic surface roughness. However, for microbial adhesion to occur, it is necessary a minimal roughness of $0.2 \mathrm{~mm}$, which is the acceptable threshold value ${ }^{22}$. In this study, only two groups showed values higher than $0.2 \mathrm{~mm}$. Listerine ${ }^{\circledR}$ after $12 \mathrm{~h}$ immersion, presented values ranging from 0.6 to $1.6 \mathrm{~mm}$. Plax alcohol-free showed an increase on roughness values after $12 \mathrm{~h}$ immersion, from 0.12 to $1.05 \mathrm{~mm}$. The $\mathrm{pH}$ of this mouthwash was 4.93 . Listerine ${ }^{\circledR}$ had the lowest $\mathrm{pH}$ value compared with other mouthwashes, showing a $\mathrm{pH}$ of 4.11 . It may be assumed that the higher acidity may have caused the degradation of the superficial layer of the acrylic resin, resulting in an increase of the roughness values. The continuous exposure of the material to these mouthwashes promoted a removal of this superficial layer, exposing a subsurface region of the acrylic resin, which could explain the decreased roughness values from 24 h to 7 days immersion in $\operatorname{Plax}^{\circledR}$ alcohol-free. This roughening effect, shown in Listerine ${ }^{\circledR} 12 \mathrm{~h}$ and $\mathrm{Plax}^{\circledR}$ alcohol-free $12 \mathrm{~h}$ groups, could cause patient discomfort and became more susceptible to microorganism colonization and biofilm formation.

The softening of acrylic resin evaluated by microhardness is closely related to surface characteristics of ROA, which are subjected to continuous abrasion during cleaning methods and by storage environment. Acrylic resin immersion in all mouthwashes resulted in an increase of softening after 7 days of immersion. The Plax ${ }^{\circledR}$ alcohol-free mouthwash showed a pattern similar to mouthwashes with alcohol, probably due to superficial alterations produced by phosphoric acid. At 7 days, Periogard ${ }^{\circledR}$ showed the highest softening values over time $(p<0.05)$. Asad et al. ${ }^{23}$ showed similar results when immersed acrylic resin specimens in a $0.5 \%$ chlorhexidine gluconate solution and showed alterations of microhardness values after 7 days of storage. In the present study, test specimens were disinfected with $0.12 \%$ chlorhexidine digluconate. Periogard ${ }^{\circledR}$ is an alcohol-based mouthwash $(11.6 \%)$ and the alcohol solvent action could also explain the changes on the acrylic surface. The resin may slowly absorb the disinfectant, altering the structure of polymer ${ }^{24}$. Listerine ${ }^{\circledR}$ showed an increased softening process in all immersion times. The antibacterial activity of Listerine ${ }^{\circledR}$ is claimed to be due to the combination of four essential oils: eucalyptol, menthol, methyl salicylate, and thymol. The essential oils act on the resin surface and are a potential source of harm considering the solvent action for acrylic and other thermoplastic resins ${ }^{25}$. This may explain the increased softening showed by the acrylic resin after immersion in Listerine ${ }^{\circledR}$. At 7 days of immersion in Listerine ${ }^{\circledR}$, the specimens showed a slight but significant increase in final hardness values, and decrease of softening, which is in accordance with the softening effect of ethanol on acrylic resins ${ }^{6,24}$. It seems that ethanol, as well as water, helps moving the polymer chains apart and allows them to slide (deform plastically) more easily ${ }^{6}$. This decrease in final hardness values for PMMA is also caused by the plasticization effect enhanced by ethanol, which penetrates the matrix and expands the space between the chains ${ }^{26}$.

Colorimetric analysis using the $\Delta \mathrm{E}$ as a parameter, showed that at the 12-h immersion period, Listerine ${ }^{\circledR}$ presented a significantly greater variation compared to other mouthwashes, probably due to changes in surface topography of the acrylic resin that influence the parameters of colorimetric measurement ${ }^{27-28}$. Moreover, there was visible interaction of the green dye (CI 42053) in Listerine ${ }^{\circledR}$ with the acrylic resin, especially after a $12 \mathrm{~h}$ immersion, confirmed by the colorimetric assessment. This colorant influences the values of $-\mathrm{a}^{*}$ and $+\mathrm{b}^{*}$ parameters, changing the final $\Delta \mathrm{E}$ by an increase in $\Delta \mathrm{a}$ and $\Delta \mathrm{b}$ of the samples. This could be explained by what is referred to as a crowding effect ${ }^{29}$, when higher pigment concentrations result in an interaction among the colorant particles and lead to deviation from the linear behavior. Regarding the Plax ${ }^{\circledR}$ alcohol-free, Plax ${ }^{\circledR}$ Classic and Periogard ${ }^{\circledR}$ groups, the lack of significant difference in the values of $\Delta \mathrm{E}$ among times within the groups can be related to changes on the surface, since in such groups the difference in roughness also showed no significance ${ }^{27-28}$.

The limitations of this study include the fact that the immersion procedures were conducted without time intervals and the specimens were subjected to the mouthwash action continuously. The patients do not expose continuously their removable appliances to mouthwash solutions. The immersion procedures are intermittent, and use of an acrylic device in oral environment between immersion periods could elute chemical components like ethanol and acids during the use. Then, the acrylic resin will adsorb water molecules, which act as a plasticizer to a lesser extent than ethanol. In other words, the harmful effects on acrylic resin surface and color might be less significant. However the influence of immersion in mouthwashes could represent several months of acrylic device use, considering daily immersions.

It was concluded that immersion in mouthwashes could influence acrylic resin hardness, roughness and color. It is therefore recommenced that the orthodontist indicates mouthwashes to their patients with caution when establishing an at-home disinfection protocol.

\section{Acknowledgements}

The authors would like to express their gratitude to the Brazilian Government through CAPES (Coordination of Improvement of Higher Education Personnel) for the financial support provided and the professor Carlos Otávio Petter from the LAPROM laboratory (Mineral Processing Laboratory) of the Federal University of Rio Grande do Sul.

\section{References}

1. Lara-Carrillo E, Montiel-Bastida NM, Sánchez-Péres L, Alanís-Tavira J. Effect of orthodontic treatment on saliva, plaque and the levels of Streptococcus mutans and Lactobacillus. Med Oral Patol Oral Cir Bucal. 2010; 15: 924-9. 
2. Kim K, Heimisdrottir K, Gebauer U, Persson R. Clinical and microbiological findings at sites treated with orthodontic fixed appliances in adolescents. Am J Orthod Dentofacial Orthop. 2010; 137: 223-8.

3. Batoni G, Pardini M, Giannotti A, Ota F, Giuca MR, Gabriele M. Effect of removable orthodontic appliances on oral colonization by mutans streptococci in children. Eur J Oral Sci. 2001; 109: 388-92.

4. Lessa FCR, Enoki C, Ito IY, Faria G, Aiko M, Matsumoto N, Nelson-Filho $P$. In-vivo evaluation of the bacterial contamination and disinfection of acrylic baseplates of removable orthodontic appliances. Am J Orthod Dentofacial Orthop. 2007; 131: 11-7.

5. Glass RT, Conrad RS, Bullard JW, Goodson LB, Mehta N, Lech SJ et al. Evaluation of microbial flora found in previously worn prostheses from the Northeast and Southwest regions of the United States. J Prosthet Dent. 2010; 103: 384-9.

6. Pavarina AC, Machado AL, Giampaolo ET, Vergani CE. Effects of chemical disinfectants on the transverse strength of denture base acrylic resins. J Oral Rehabil. 2003; 30: 1085-9.

7. Brightman LJ, Terezhalrny GT, Greenwell H, Jacobs M, Enlow DH. The effects of a $0.12 \%$ chlorhexidine gluconate mouthrinse on orthodontic patients aged 11 through 17 with established gingivitis. Am J Orthod Dentofacial Orthop. 1991; 100: 324-9.

8. Pan PC, Harpera S, Ricci-Nittela D, Luxb R, Shi W. In-vitro evidence for efficacy of antimicrobial mouth rinses. J Dent. 2010; 38 (Suppl 1): 16-20.

9. Oyanagi T, Tagami J, Matin K. Potentials of Mouthwashes in Disinfecting Cariogenic Bacteria and Biofilms Leading to Inhibition of Caries. Open Dent J. 2012; 6: 23-30.

10. Raangs GC, Winkel EG, van Winkelhoff AJ. In vitro antimicrobial effects of two antihalitosis mouth rinses on oral pathogens and human tongue microbiota. Int J Dent Hyg. 2013; 11: 203-7.

11. Shim JY, Yim SB, Chung JH, Hong KS. Antiplaque and antigingivitis effects of a mouthrinse containing cetylpyridinium chloride, triclosan and dipotassium glycyrrhizinate. J Periodontal Implant Sci. 2012; 42: 33-8.

12. Ferracane JL. Hygroscopic and hydrolytic effects in dental polymer networks. Dent Mater. 2006; 22: 211-22.

13. Subramanya JK, Muttagi S. In vitro color change of three dental veneering resins in tea, coffee and tamarind extracts. J Dent. 2011; 8: 138-45.

14. Lee $\mathrm{H}$, Lee $\mathrm{C}$, Asaoka K. Correlation in the mechanical properties of acrylic denture base resins. Dent Mater J. 2012; 31: 157-64.

15. Neppelenbroek KH, Pavarina AC, Vergani CE, Giampaolo ET. Hardness of heat-polymerized acrylic resins after disinfection and long-term water immersion. J Prosthet Dent. 2005; 93: 171-6.

16. Fernandes FHCN, Orsi IA, Villabona CA. Effects of the peracetic acid and sodium hypochlorite on the colour stability and surface roughness of the denture base acrylic resins polymerised by microwave and water bath methods. Gerodontology. 2013; 30: 18-25.

17. Miranda D de A, Bertoldo CE, Aguiar FH, Lima DA, Lovadino JR. Effects of mouthwashes on Knoop hardness and surface roughness of dental composites after different immersion times. Braz Oral Res. 2011; 25: 168-73.

18. Subramaniam $P$, Nandan $N$. Effect of xylitol, sodium fluoride and triclosan containing mouth rinse on Streptococcus mutans. Contemp Clin Dent. 2011; 2: 287-90.

19. Takeshita T, Suzuki N, Nakano Y, Shimaki Y, Yoneda M, Hirofuji T, Yamashita Y. Relationship between oral malodor and the global composition of indigenous bacterial populations in saliva. Appl Environ Microbiol. 2010; 76: 2806-14.

20. Marcos-Arias C, Eraso E, Madariaga L, Quindós G. In vitro activities of natural products against oral Candida isolates from denture wearers. BMC Complement Altern Med. 2011; 26: 11: 119.

21. Mavreas D, Athanasiou AE. Factors affecting the duration of orthodontic treatment: a systematic review. Eur J Orthod. 2008; 30: 386-95.

22. Bollen CM, Lambrechts $P$, Quirynen M. Comparison of surface roughness of oral hard materials to the threshold surface roughness for bacterial plaque retention: a review of the literature. Dent Mater. 1997; 13: 258-69.
23. Asad T, Watkinson AC, Huggett R. The effects of various disinfectant solutions on the surface hardness of acrylic resin denture base material. Int J Prosthodont. 1993; 6: 9-12.

24. Vlissidis $D$, Prombonas $A$. Effect of alcoholic drinks on surface quality and mechanical strength of denture base materials. J Biomed Mater Res. 1997; 38: 257-61.

25. Smith DC. The cleansing of dentures. Dent Pract Dent Rec. 1966; 17 39-43.

26. Polydorou $\mathrm{O}$, Trittler R, Hellwiga E. Elution of monomers from two conventional dental composite materials. Dent Mater. 2007; 23: 1535-41.

27. Kingery WD. Introduction to ceramics. New York: Wiley; 1960.

28. Ghinea RG, Ugarte-Alvan L, Yebra A, Pecho OE, Paravina RD, Perez MDM. Influence of surface roughness on the color of dental-resin composites. J Zhejiang Univ Sci B. 2011; 12: 552-62.

29. No IA, Kleist ULF, Rigdahl M. Color of pigmented plastics - measurements and predictions. Polym Plast Technol Eng. 2004; 44: 141-52. 